総説

\title{
炭酸基を含む新しい酸化物超伝導体
}

山根 久典, 宮崎 譲, 平井 敏雄

東北大学金属材料研究所， 9980 仙台市青葉区片平2-1-1.

\section{New Oxide Superconductors Containing Carbonate Groups}

Hisanori Yamane, Yuzuru Miyazaki and Toshio Hirai

Institute for Materials Research, Tohoku University, 2-1-1 Katahira Aoba-ku, Sendai 980.

Received November 26, 1992

Studies of newly discovered cuprates and cuprate superconductors containing carbonate groups were reviewed. Carbonate groups $\left(\mathrm{CO}_{3}\right), \mathrm{CuO}$ and alkali-earth elements ( $\mathrm{Sr}, \mathrm{Ba}$ ) comprised new block layers of $\left[(\mathrm{Sr}, \mathrm{Ba})_{2}(\mathrm{C}, \mathrm{Cu}) \mathrm{O}_{x}\right]$. Combination of the block layers containing $\mathrm{CO}_{3}$ and previously known block layers (oxygen-deficient metal layers or fluorite layers) brought new compounds and superconductors. Superconducting transition temperatures of $\left(\mathrm{Sr}_{1-x} \mathrm{Ba}_{\mathrm{x}}\right)_{2} \mathrm{Cu}_{1+y} \mathrm{O}_{2+2 y+d}\left(\mathrm{CO}_{3}\right)_{1-y}, \quad\left(\mathrm{Y}_{0.5} \mathrm{Ca}_{0.5}\right)_{0.95} \mathrm{Sr}_{2.05} \mathrm{Cu}_{2.4} \mathrm{O}_{x}\left(\mathrm{CO}_{3}\right)_{0.6}$ and $\left(\mathrm{Y}_{0.73} \mathrm{Ce}_{0.27}\right)_{2} \mathrm{Sr}_{2} \mathrm{Cu}_{2.65} \mathrm{O}_{x}\left(\mathrm{CO}_{3}\right)_{0.35}$ were around 40,68 and $17 \mathrm{~K}$, respectively.

\section{1はじめに}

これまでに発見された銅系酸化物超伝導体 は、いずれも $\mathrm{CuO}_{2}$ 面とその間に挟まれるブロッ ク層と呼ばれる金属元素や金属一酸素層により 構成されており、プロック層の種類やそれらの 皘層形態で分類がなされている1.2\%。そのため、 既知のプロック層の新しい組み合わせに加え、

本稿は平成 4 年度秋期大会特别講演「炭酸基を含む新 しい酸化物超伝学体」（山根久典）をもとにまとめたもの である。
新たなプロック層の発見は新しい銅系酸化物超 伝導体の探索領域を広げる上で重要な意味を持 つ。

最近、従来より知られていた金属原子や金属原 子と酸素からなるブロック層以外にイオン基の一 つである炭酸基 $\left(\mathrm{CO}_{3}{ }^{2 \cdot}\right)$ が $\mathrm{CuO}_{2}$ 面間のブロック 層を構成することが明らかにされ、炭酸基を含む 新しい超伝尊体か発見された。本稿では、炭酸基 を含む銅系酸化物の合成と結晶構造およびその超 伝導について最近の研究を紹介する。 
2 嵌酸基を含む新物容の合成、

楼造と超伝道

\section{$2.1 \mathrm{Sr}_{2} \mathrm{CuO}_{2}\left(\mathrm{CO}_{3}\right)$ の合成と結晶構造}

炭酸基を含を銅系酸化物 $\mathrm{Sr}_{2} \mathrm{CuO}_{2}\left(\mathrm{CO}_{3}\right)$ の存在は 既に4年ほど前にSchneringらによって報告され ていたが3)、当時この物質は $\mathrm{Sr}_{2} \mathrm{CuO}_{3}$ が生成する 際の中間反応生成物と考えられていた。その 後、Babuらは中性子回折によりこの物質の秸晶

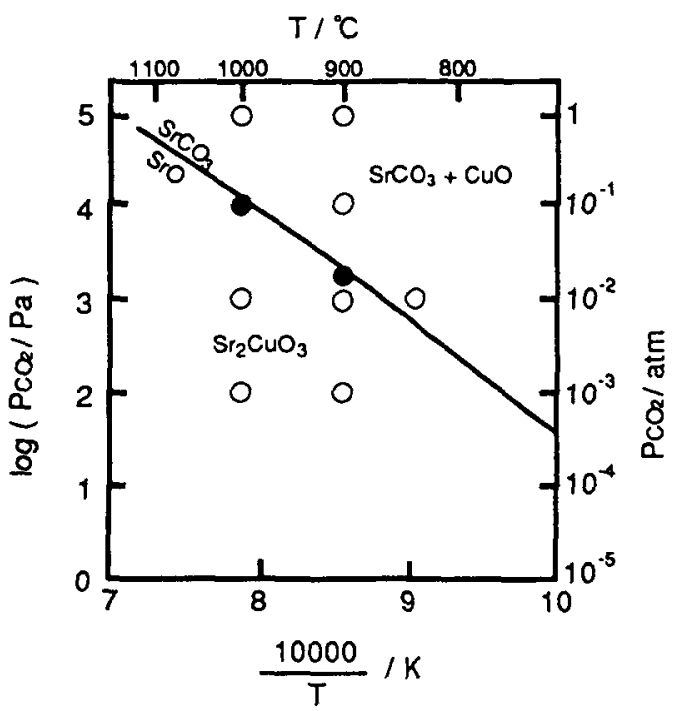

Fig. 1 Conditions of temperature and $\mathrm{CO}_{2}$ partial pressure for preparation of $\mathrm{Sr}_{2} \mathrm{CuO}_{2}\left(\mathrm{CO}_{3}\right)(\bullet)$.
構造解析を行ったが、彼らもこの物質を中間 生成物として扱っており、解析に用いられた 試料にはS $\mathrm{SrCO}_{3}$ が含まれていたい。

著者らは、焼成時のCO $\mathrm{CO}_{2}$ 分圧をFig.1に・て 示すような $\mathrm{SrCO}_{3}=\mathrm{SrO}+\mathrm{CO}_{2}$ の平衙 $\mathrm{CO}_{2}$ 分圧付 近にすると $\mathrm{Sr}_{2} \mathrm{CuO}_{2}\left(\mathrm{CO}_{3}\right)$ が安定に存在できる ことを見いだし、室温まで急冷で単相試料 を得ることに成功しだ)。また、 $\mathrm{SrCO}_{3}$ の平衙 解離 $\mathrm{CO}_{2}$ 分圧付近下 900-1000 Cの条件では、 空気中で一旦生成した $\mathrm{Sr}_{2} \mathrm{CuO}_{3}$ \& $\mathrm{Sr}_{2} \mathrm{CuO}_{2}\left(\mathrm{CO}_{3}\right)$ に変化することが確認された。

$\mathrm{CO}_{2}$ 分圧を 0.1 気压に調整した需囲気 $\left(\mathrm{CO}_{2} 10 \%-\mathrm{O}_{2} 90 \%\right)$ 中 $1000^{\circ} \mathrm{C}$ で合成された $\mathrm{Sr}_{2} \mathrm{CuO}_{2}\left(\mathrm{CO}_{3}\right)$ 単相の粉末中性子回折パターン とリートベルト解析の結果をFig，2に示す。 $\mathrm{Sr}_{2} \mathrm{CuO}_{2}\left(\mathrm{CO}_{3}\right)$ の結晶構造は、格子定数 $\mathrm{a}=$ $7.8045, b=14.993 \AA$ の正方晶で、電子楾回折 パターンをもとに決められた空間群はI あった。解析により明かにされた結晶構造を Fig. 3に示す。この化合物の構造は $\mathrm{CuO}_{2}$ 面と岸 酸基を含を $\mathrm{Sr}-\mathrm{CO}_{3}-\mathrm{Sr}$ 層 $\left(\left[\mathrm{Sr}_{2} \mathrm{CO}_{3}\right]\right)$ 加構成 されており、 $\left[\mathrm{Sr}_{2} \mathrm{CO}_{3}\right]$ がブロック層となってい ることがわかる。Cのまわりに○が平面3配位 した炭酸基は、結晶構造中で規則的に配列し ている。

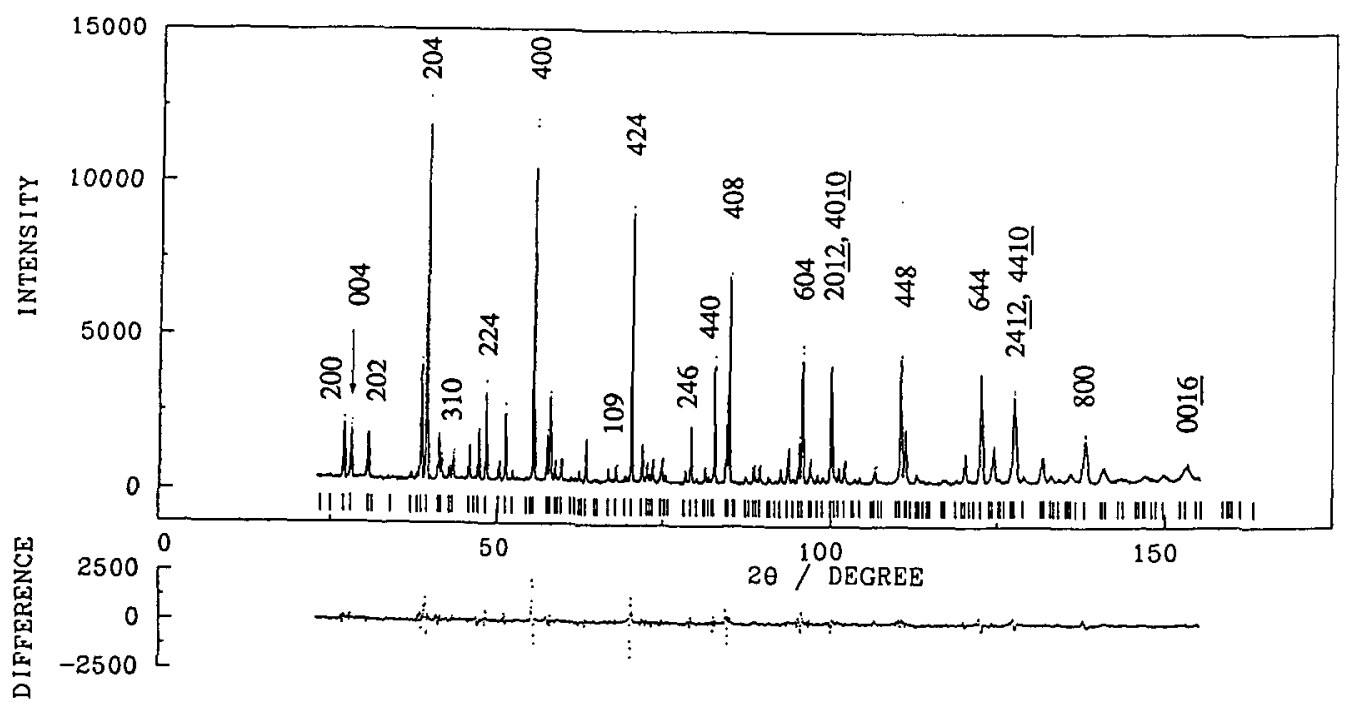

Fig. 2 Rietveld refinement profile of the neutron powder diffraction data for $\mathrm{Sr}_{2} \mathrm{CuO}_{2}\left(\mathrm{CO}_{3}\right)^{3)}$. 


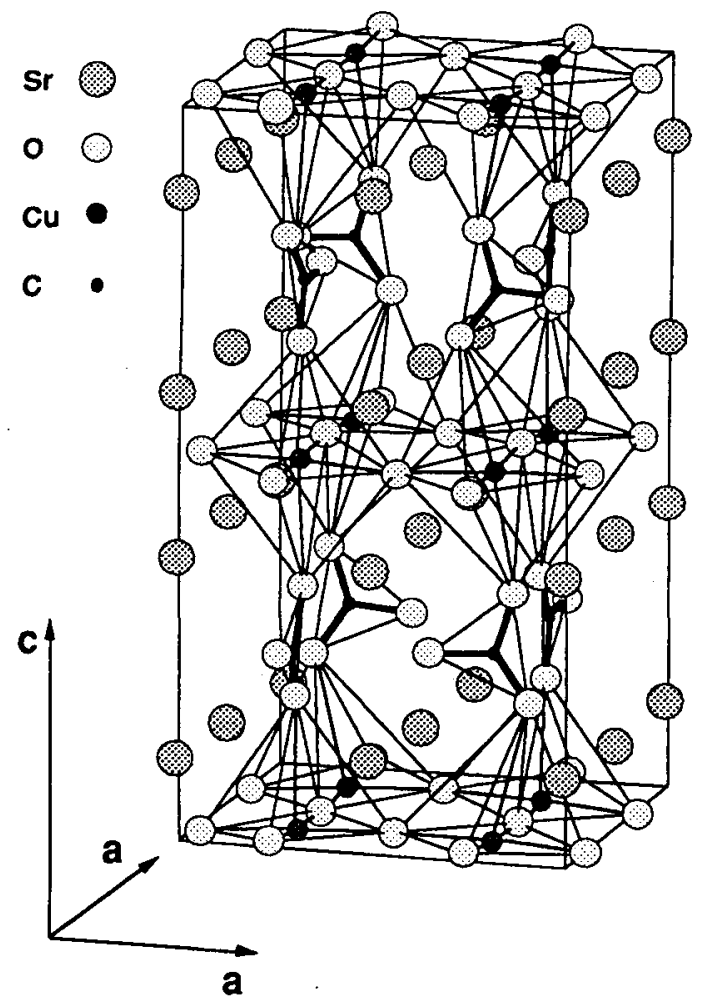

Fig.3 Crystal structure of $\mathrm{Sr}_{2} \mathrm{CuO}_{2}\left(\mathrm{CO}_{3}\right)^{5)}$.
$2.2\left(\mathrm{Sr}_{1-x} \mathrm{Ba}_{x}\right)_{2} \mathrm{Cu}_{1+y} \mathrm{O}_{2+2 y+\mathrm{d}}\left(\mathrm{CO}_{3}\right)_{1-y}$ 超伝導体

$\mathrm{CuO}_{2}$ 面と $\left[\mathrm{Sr}_{2} \mathrm{CO}_{3}\right]$ のプロック層からなる $\mathrm{Sr}_{2} \mathrm{CuO}_{2}\left(\mathrm{CO}_{3}\right)$ は、 $\mathrm{Cu}$ 洒数が +2 半導体でこ のままでは超伝導を示さないが、適当なキャ リヤーの導入により超伝導体になることが期 待されていた。こうしたなか、木下と山田は $\mathrm{Sr}_{2} \mathrm{CuO}_{2}\left(\mathrm{CO}_{3}\right)$ のrのほほ半分を $\mathrm{Ba}$ てまたた、 約 $10 \%$ の岸酸基を $\mathrm{CuO}_{\mathrm{x}}$ で置き换えた化合物 $\left(\mathrm{Sr}_{1-x} \mathrm{Ba}_{\mathrm{x}}\right)_{2} \mathrm{Cu}_{1+y} \mathrm{O}_{2+2 y+4}\left(\mathrm{CO}_{3}\right)_{1-y}(0.4 \leqq \mathrm{x} \leqq 0.65, \mathrm{y} \sim$ $0.1)$ を0気圧の酸素圧下で合成することに成功 した6)。泉らが行なった粉末中性子回折のリー トベルト解析の䊅果によると、炭酸基と $\mathrm{CuO}_{x}$ の配置は統計的になっている》。

この化合物は炭酸基を含む化合物の中では

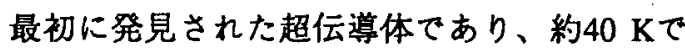
電気抵抗が下がり始め、26 Kでぜ口抵抗を示 した。キャリヤーは約10\%の炭酸基が $\mathrm{CuO}$ で 置き換わったことにより導入されたと考えら れている。

\section{$2.3 \mathrm{Y}_{2} \mathrm{Sr}_{5} \mathrm{Cu}_{6} \mathrm{O}_{13.5}\left(\mathrm{CO}_{3}\right)_{0.9}$ の合成と結晶構造}

炭酸基を含を層が新たなブロック層となる ことが明らかにされたことから、従来より知 られていたプロック層との組合せによる新し い超伝導体の探索も試みられた。既存のブ

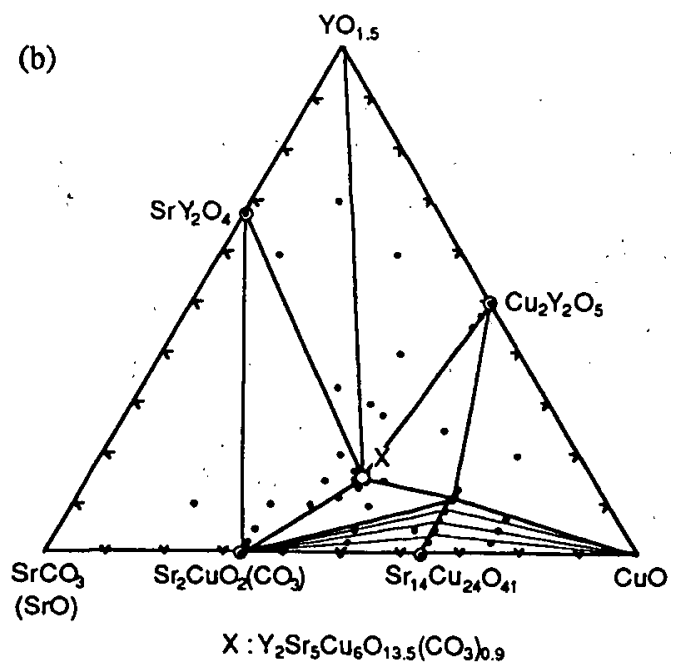

Fig. 4 Products obtained in the system of $\mathrm{SrO}-\mathrm{Y}_{2} \mathrm{O}_{3}-\mathrm{CuO}_{\mathrm{x}}$ at $1000^{\circ} \mathrm{C}$ under $\mathrm{PO}_{2}=1 \mathrm{~atm}$ (a) and in the system of $\mathrm{SrCO}_{3}(\mathrm{SrO})-\mathrm{Y}_{2} \mathrm{O}_{3}-\mathrm{CuO}_{x}$ under $\mathrm{PO}_{2}=0.9$ and $\mathrm{PCO}_{2}=0.1 \mathrm{~atm}(\mathrm{~b})^{8}$. 
ロック痛のうち初めに試みられたのは、Yのブ ロック層との組合せであった。Fig.4の(a)に示す ように酸素票囲気中 $1000^{\circ} \mathrm{C} て ゙ は \mathrm{Y}_{2} \mathrm{O}_{3}-\mathrm{SrO}-\mathrm{CuO}$ 系内に $\mathrm{Sr}_{14} \mathrm{Cu}_{24} \mathrm{O}_{41}$ のY固溶相以外の化合物は存在 しないが、1000 C、 $\mathrm{CO}_{2} 10 \%-\mathrm{O}_{2} 90 \%$ の需囲気 下では、新しい化合物 $\mathrm{Y}_{2} \mathrm{Sr}_{5} \mathrm{Cu}_{6} \mathrm{O}_{13.5}\left(\mathrm{CO}_{3}\right)_{0.9}$ が合 成された（Fig.4(b)）8)。

この物質の電子楾回折バターンのうち $a^{*}-c^{*}$ 面 内では 方向に2倍の長周期反射がみられた9。高分解能 電子顕微鏡観察により䊅晶構造が $\mathrm{YBa}_{2} \mathrm{Cu}_{3} \mathrm{O}_{\mathrm{x}}$ の 結晶構造に類似していることが明らかになっ た。a-b面内では、炭素の位置を示すと考えられ る明るい部分が電子楾回折バターンと対応して 軸方向にa軸長の 2 から3倍、c軸方向にc軸長の2 倍の周期で観察された。さらに粉末中性子回折 バターンのリートベルト解析により統計的な基 本構造 $(a=3.8278, b=3.8506, c=11.1854 \AA)$ が明 らかにされた9。解析された基本構造や高分解能 電子顕微鏡観察の結果をもとに推定した局所構 造をFig. 5に示す。この新物質の構造は $\mathrm{Sr}_{\mathrm{r}}$ と $\mathrm{CO}_{3}$ 基、 $\mathrm{CuO}$ 鎖からなるブロック層 $\left[\mathrm{Sr}_{2}(\mathrm{C}, \mathrm{Cu}) \mathrm{O}_{\mathrm{x}}\right]$ と 酸素久損Y-Sr金属のブロック層の組合せで説明 することができる。平面3配位の炭酸基はa-c面

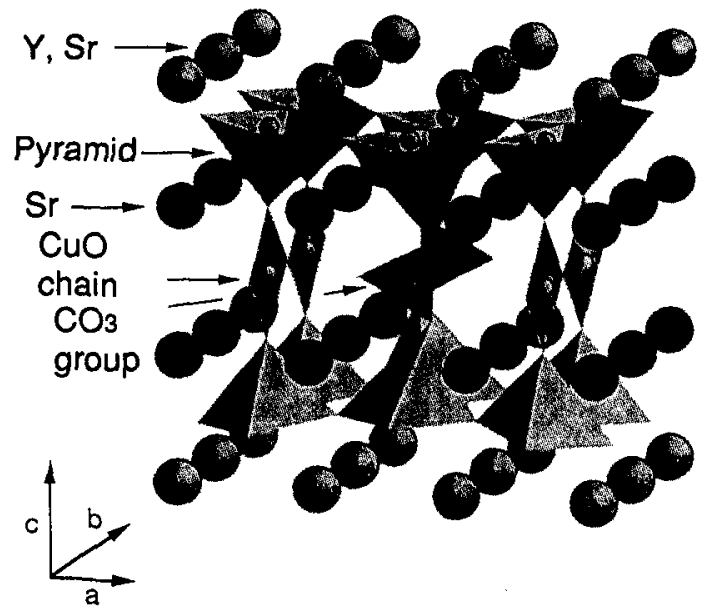

Fig. 5 Local crystal structure of $\mathrm{Y}_{2} \mathrm{Sr}_{5} \mathrm{Cu}_{6} \mathrm{O}_{13.5}\left(\mathrm{CO}_{3}\right)_{0.9}$.
内に平行に位置しており、 $\mathrm{CuO}$ 鎖が $b$ 軸方向に

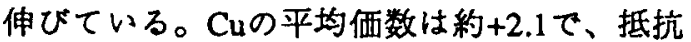
率の温度変化は半導体的であり、超伝導転移 はみられなかった。

\section{$2.4\left(\mathrm{Y}_{0.5} \mathrm{Ca}_{0.5}\right)_{0.95} \mathrm{Sr}_{205} \mathrm{Cu}_{2 .} \mathrm{O}_{x}\left(\mathrm{CO}_{3}\right)_{0.6}$ 超伝導体} $\mathrm{Y}_{2} \mathrm{Sr}_{5} \mathrm{Cu}_{6} \mathrm{O}_{13.5}\left(\mathrm{CO}_{3}\right)_{0.9}$ をとと超伝導体を 目的として、 $\mathrm{Y}^{3+} \mathrm{Ca}^{2+}$ に置換することによる キャリアーの莩入が試みられた。秋光らは、 $\mathrm{CO}_{2} 20 \%-\mathrm{O}_{2} 80 \%$ 雾囲気中 $1050^{\circ} \mathrm{C} て ゙$ 焼成するこ とにより $\left(\mathrm{Y}_{0.5} \mathrm{Ca}_{0.5}\right)_{0.95} \mathrm{Sr}_{205} \mathrm{Cu}_{24} \mathrm{O}_{\mathrm{x}}\left(\mathrm{CO}_{3}\right)_{0.6}$ を合成 し、 $0.1 \% \sigma \mathrm{CO}_{2}$ 含む100気压のO 雲囲気下 $700^{\circ} \mathrm{Cで}$ 加熱処理を行なって超伝導体を得るこ とに成功した10) Fig. 6にこの超伝導体の抵抗

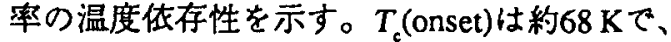
$38 \mathrm{~K}$ で抵抗がゼロとなった。また、Fig.7に帯 磁率の温度位存性を測定した結果を示す。こ

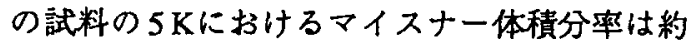
5\%であったが、最近の研究で酸素的40気质 $1000^{\circ}$ Cの処理により $17 \%$ まで增えることが確 認されている。

\section{$2.5\left(\mathrm{Y}_{0.73} \mathrm{Ce}_{0.27}\right)_{2} \mathrm{Sr}_{2} \mathrm{Cu}_{2.65} \mathrm{O}_{2}\left(\mathrm{CO}_{3}\right)_{0.35}$ 超伝導体}

炭酸基を含むブロック層 $\left[\mathrm{Sr}_{2}(\mathrm{C}, \mathrm{Cu}) \mathrm{O}_{\mathrm{x}}\right]$ に蛍石 型層を組み合わせることも試みられ、 $\left(\mathrm{Y}_{0.73} \mathrm{Ce}_{0.27}\right)_{2} \mathrm{Sr}_{2} \mathrm{Cu}_{265} \mathrm{O}_{\mathrm{x}}\left(\mathrm{CO}_{3}\right)_{0.35}$ の新しい化合物 が $\mathrm{CO}_{2} 20 \%-\mathrm{O}_{2} 80 \%$ の雾囲気中 $1030^{\circ} \mathrm{C}$ で合成

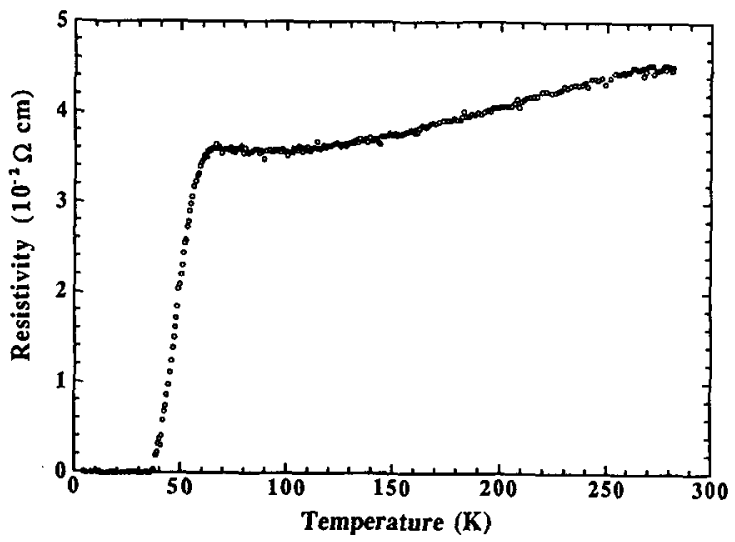

Fig. 6 Resistivity vs. temperature for $\left(\mathrm{Y}_{0.5} \mathrm{Ca}_{0.5}\right)_{0.95} \mathrm{Sr}_{20.5} \mathrm{Cu}_{2.4} \mathrm{O}_{\mathrm{x}}\left(\mathrm{CO}_{3}\right)_{0.6}{ }^{10)}$. 


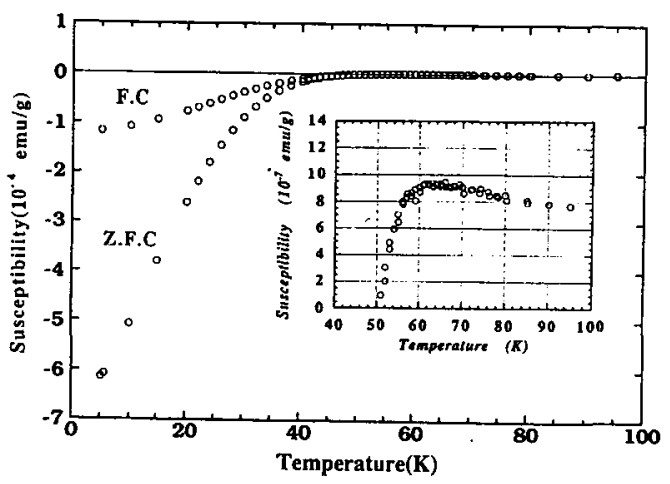

Fig. 7 Magnetic susceptibility vs. temperature for $\left(\mathrm{Y}_{0.5} \mathrm{Ca}_{0.5}\right)_{0.95} \mathrm{Sr}_{2.05} \mathrm{Cu}_{2.4} \mathrm{O}_{\mathrm{x}}\left(\mathrm{CO}_{3}\right)_{0.6}{ }^{10 \%}$.

されだ。この試料は、900気圧の高圧酸素中 $750^{\circ}$ Cで処理することにより、5 Kでの体積分率 が約10\%のバルクの超伝導特性が確認された。 Fig.8にこの超伝導体の带磁率の温度変化を示

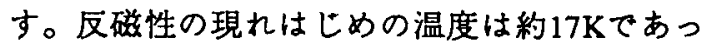
た。Fig.9に $\left(\mathrm{Y}_{0.73} \mathrm{Ce}_{0.27}\right)_{2} \mathrm{Sr}_{2} \mathrm{Cu}_{2.65} \mathrm{O}_{\mathrm{x}}\left(\mathrm{CO}_{3}\right)_{0.35}$ の抵抗 率の温度变化を示す。高圧酸素処理した試料は $120 \mathrm{~K}$ まで金属的な挙動を示し、15 K付近から急 激に抵抗率が減少して5 Kで抵抗がゼロになっ た。

高圧酸妻処理後の試料のX線回折パターンと リートベルト解析の結果をFig. 10に、また、b軸 方向からみた結晶構造をFig. 11に示す。高圧酸

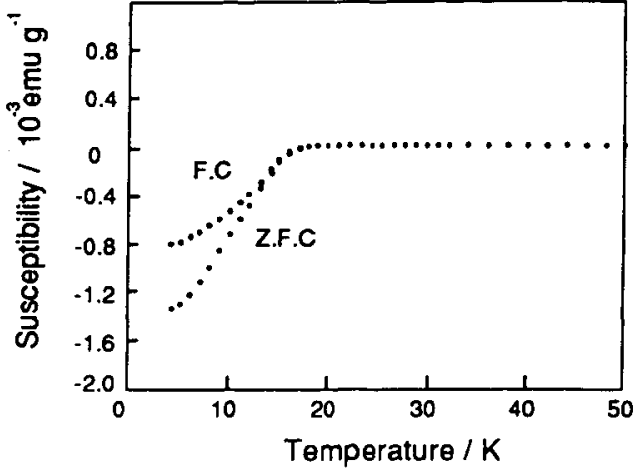

Fig. 8 Magnetic susceptibility vs. temperature for $\left(\mathrm{Y}_{0.73} \mathrm{Ce}_{0.27}\right)_{2} \mathrm{Sr}_{2} \mathrm{Cu}_{2.65} \mathrm{O}_{x}\left(\mathrm{CO}_{3}\right)_{0.35}{ }^{11)}$.

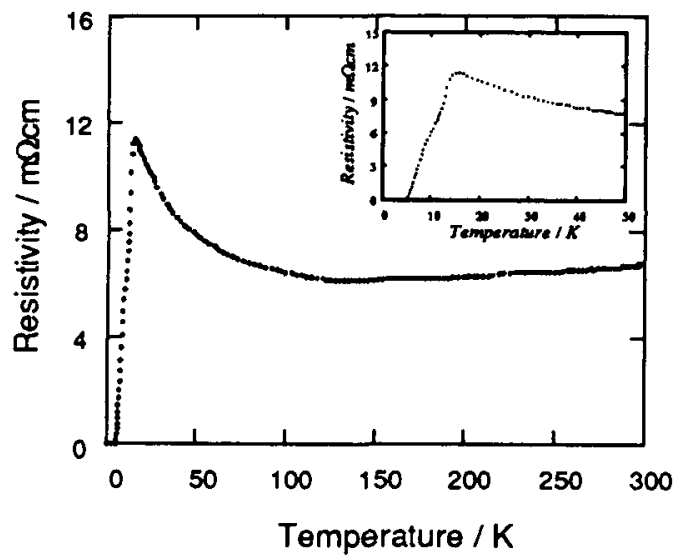

Fig. 9 Resistivity vs. temperature for $\left(\mathrm{Y}_{0.73} \mathrm{Ce}_{0.27}\right)_{2} \mathrm{Sr}_{2} \mathrm{Cu}_{265} \mathrm{O}_{\mathbf{x}}\left(\mathrm{CO}_{3}\right)_{0.35}{ }^{11)}$.

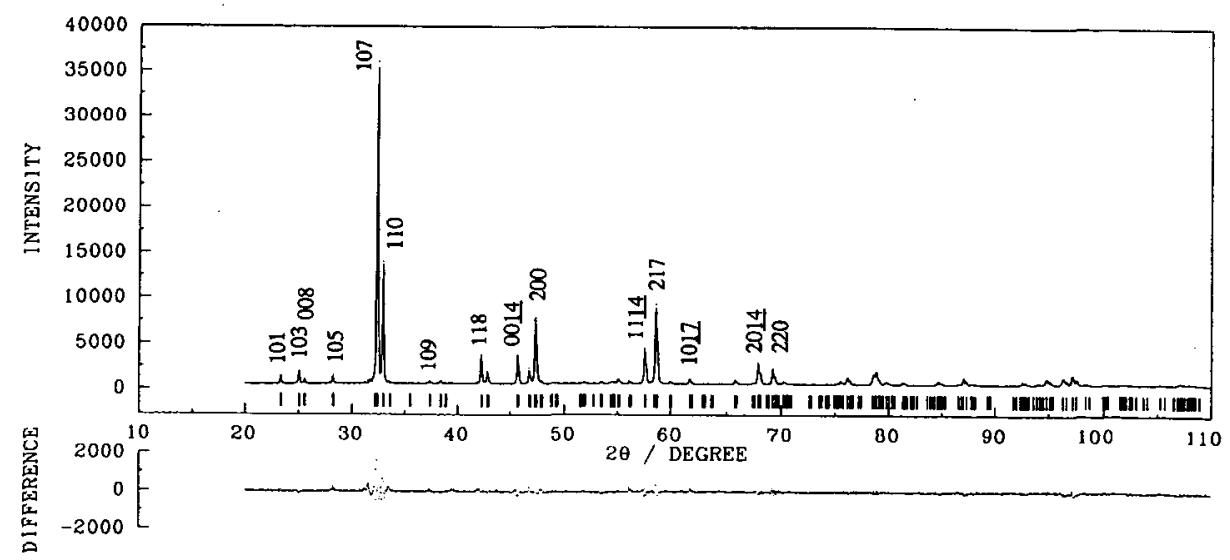

Fig. 10 Rietveld refinement profile of the $\mathrm{X}$-ray powder diffraction data for $\left(\mathrm{Y}_{0.73} \mathrm{Ce}_{0.27}\right)_{2} \mathrm{Sr}_{2} \mathrm{Cu}_{2.65} \mathrm{O}_{\mathrm{x}}\left(\mathrm{CO}_{3}\right)_{0.35}{ }^{11}$. 


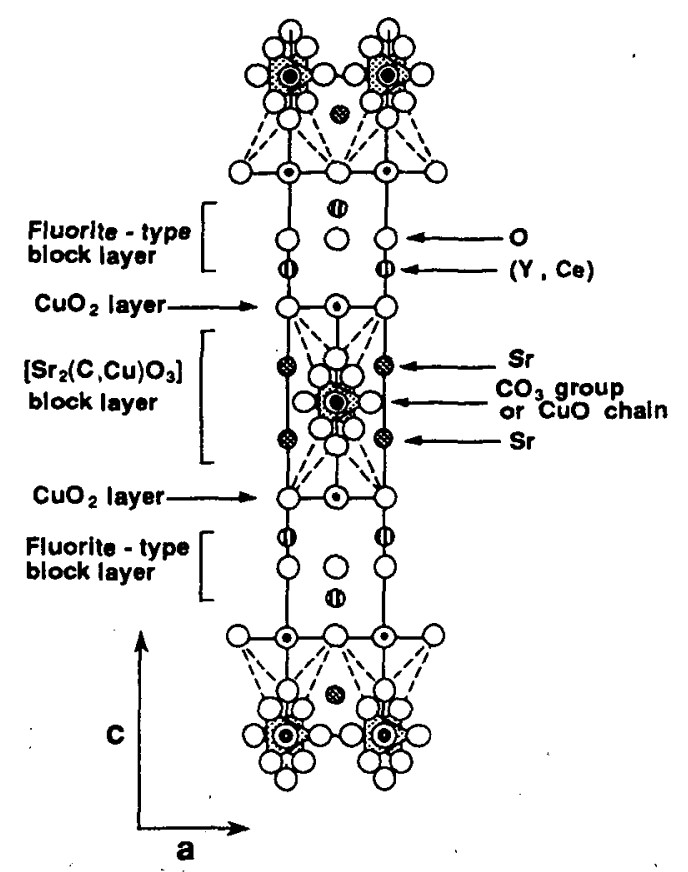

Fig. 11 Projection of the crystal structure of $\left(\mathrm{Y}_{0.73} \mathrm{Ce}_{0.27}\right)_{2} \mathrm{Sr}_{2} \mathrm{Cu}_{2.65} \mathrm{O}_{x}\left(\mathrm{CO}_{3}\right)_{0.35}{ }^{\prime \prime \prime}$.

素処理前の試料の格子定数は、 $a=3.832(1), c=$ $27.7104(8) \AA の$ 正方晶であった。超伝導試料の格 子定数は $a=3.8272(1), b=3.8313(1), c=$ $27.7077(6) \AA の$ 斜方晶で、処理前のものと比べa 軸およびc軸の長さが減少している。

\section{了おわりに}

炭酸基を含む化合物および超伝導体は、以上 紹介した $\mathrm{Sr}_{2} \mathrm{CuO}_{2}\left(\mathrm{CO}_{3}\right),\left(\mathrm{Sr}_{1 \cdot \mathrm{x}} \mathrm{Ba}_{\mathrm{x}}\right)_{2} \mathrm{Cu}_{1+\mathrm{y}} \mathrm{O}_{2+2 \mathrm{y}+\mathrm{d}}$ $\left(\mathrm{CO}_{3}\right)_{1-y}, \mathrm{Y}_{2} \mathrm{Sr}_{5} \mathrm{Cu}_{6} \mathrm{O}_{13.5}\left(\mathrm{CO}_{3}\right)_{0.9},\left(\mathrm{Y}_{0.5} \mathrm{Ca}_{0.5}\right)_{0.95} \mathrm{Sr}_{2.05}$ $\mathrm{Cu}_{24} \mathrm{O}_{x}\left(\mathrm{CO}_{3}\right)_{0.6},\left(\mathrm{Y}_{0.73} \mathrm{Ce}_{0.27}\right)_{2} \mathrm{Sr}_{2} \mathrm{Cu}_{265} \mathrm{O}_{\mathrm{x}}\left(\mathrm{CO}_{3}\right)_{0.35}$ と いった炭酸基 $\left(\mathrm{CO}_{3}\right)$ が含まれていることを中心と した表記の他に、Bi系やTl系、Pb系の超伝導体 で用いられているようなブロック層を意識した 表記12,12)で表すことができる。これに従うと、 ここで紹介した炭酸基を含む化合物や超伝導体 はそれそれ $\mathrm{CSr}_{2} \mathrm{CuO}_{5},(\mathrm{C}, \mathrm{Cu})(\mathrm{Sr}, \mathrm{Ba})_{2} \mathrm{CuO}_{x}(\mathrm{Cl} 201)$, $\left(\mathrm{C}_{0.4} \mathrm{Cu}_{0.6}\right) \mathrm{Sr}_{2}\left(\mathrm{Y}_{0.86} \mathrm{Sr}_{0.14}\right) \mathrm{Cu}_{2} \mathrm{O}_{7},(\mathrm{C}, \mathrm{Cu})(\mathrm{Sr}, \mathrm{Ca})_{2}(\mathrm{Y}$, $\mathrm{Ca}, \mathrm{Sr}) \mathrm{Cu}_{2} \mathrm{O}_{7},(\mathrm{C} 1212),\left(\mathrm{C}_{0.35} \mathrm{Cu}_{0.85}\right) \mathrm{Sr}_{2}\left(\mathrm{Y}_{0.73} \mathrm{Ce}_{0.27}\right)_{2}$ $\mathrm{Cu}_{2} \mathrm{O}_{x}(\mathrm{C} 1222)$ と表すことができ、C系として分類

\section{される。}

炭酸基が新たなブロック層を構成し、従来 から知られていたブロック層と組み合わせる ことが可能となったことから、今後、C系超伝 導体のファミリーの全容が次第に明らかにさ れるものと期待される。

\section{文辣}

1) Y. Tokura and T. Arima : Jpn. J. Appl. Phys., 29 (1990) 2388.

2) 秋光 純, 富本晃吉: 日本䊅晶学会誌, 34 (1992) 273.

3) H.G. von Schnering, M. Hartweg, L. Walz, T.

Popp, T. Becker and M. Schwarz :

Jahresbericht des MPI für Festkörperforschung Stuttgart, (1988) 94.

4) T.G.N. Babu, D.J. Fish and C. Greaves : J.

Mater. Chem., 1 (1991) 677.

5) Y. Miyazaki, H. Yamane, T. Kajitani, T. Oku, K. Hiraga, Y. Morii, K. Fuchizaki, S. Funahashi and T. Hirai : Physica C, 191 (1992) 434.

6) K. Kinoshita and T. Yamada : Nature, 357 (1992) 313.

7) F. Izumi, K. Kinoshita, Y. Matsui, K. Yanagisawa, T. Ishigaki, T. Kamiyama, T. Yamada and H. Asano : Physica C, 196 (1992) 227.

8) Y. Miyazaki, H. Yamane and T. Hirai : Physica C, 198 (1992) 53.

9) Y. Miyazaki, H. Yamane, N. Ohnishi, T. Kajitani, K. Hiraga, Y. Morii, S. Funahashi and T. Hirai : Physica C, 198 (1992) 7.

10) J. Akimitsu, M. Uehara, M. Ogawa, H. Nakata, K. Tomimoto, Y. Miyazaki, H. Yamane, T. Hirai, K. Kinoshita and Y. Matsui : Physica C, 201 (1992) 320.

11) Y. Miyazaki, H. Yamane, N. Kobayashi, T. Hirai, H. Nakata, K. Tomimoto and J. Akimitsu : Physica C, 202 (1992) 162.

12）常盤文子, 庄野安彦：固体物理, 25 (1990) 97. 